\title{
Correction to: Active human herpesvirus infections in adults with systemic lupus erythematosus and correlation with the SLEDAI score
}

Alex Domingos Reis ${ }^{1 \dagger}$, Cristiane Mudinutti $^{1 \dagger}$, Murilo de Freitas Peigo ${ }^{1 \dagger}$, Lucas Lopes Leon ${ }^{1}$, Lilian Tereza Lavras Costallat ${ }^{2}$, Claudio Lucio Rossi ${ }^{3}$, Sandra Cecília Botelho Costa ${ }^{1}$ and Sandra Helena Alves Bonon ${ }^{1 *}$

\section{Correction to: Adv Rheumatol 60, 42 (2020)} https://doi.org/10.1186/s42358-020-00144-6

After publication of the original article [1], the authors identified an error in the author' names of dr. Alex Domingos Reis.

The incorrect author' name is: Alex Domingos dos Reis

The correct author' name is: Alex Domingos Reis

The author group has been updated above and the original article [1] has been corrected.

\section{Author details}

'Laboratory of Virology, School of Medical Sciences, State University of Campinas (UNICAMP), Rua Tessália Vieira de Camargo, 126, Campinas, SP 13.083-887, Brazil. ${ }^{2}$ Department of Internal Medicine, Discipline of Rheumatology, School of Medical Sciences, State University of Campinas (UNICAMP), Campinas, SP, Brazil. ${ }^{3}$ Department of Clinical Pathology, School of Medical Sciences, State University of Campinas (UNICAMP), Campinas, SP, Brazil.

Published online: 11 September 2020

\section{Reference}

1. Reis, et al. Active human herpesvirus infections in adults with systemic lupus erythematosus and correlation with the SLEDAI score. Adv Rheumatol. 2020;60:42 https://doi.org/10.1186/s42358-020-00144-6.

The original article can be found online at https://doi.org/10.1186/s42358020-00144-6.

*Correspondence: sbonon@unicamp.br

${ }^{\dagger}$ Alex Domingos Reis, Cristiane Mudinutti and Murilo de Freitas Peigo contributed equally to this work.

'Laboratory of Virology, School of Medical Sciences, State University of Campinas (UNICAMP), Rua Tessália Vieira de Camargo, 126, Campinas, SP 13.083-887, Brazil

Full list of author information is available at the end of the article

(C) The Author(s). 2020 Open Access This article is licensed under a Creative Commons Attribution 4.0 International License, which permits use, sharing, adaptation, distribution and reproduction in any medium or format, as long as you give appropriate credit to the original author(s) and the source, provide a link to the Creative Commons licence, and indicate if changes were made. The images or other third party material in this article are included in the article's Creative Commons licence, unless indicated otherwise in a credit line to the material. If material is not included in the article's Creative Commons licence and your intended use is not permitted by statutory regulation or exceeds the permitted use, you will need to obtain permission directly from the copyright holder. To view a copy of this licence, visit http://creativecommons.org/licenses/by/4.0/. 